\title{
How Youtube Beauty Vlogger Review, Self Congruity, and Price Perception Influence Impulse Buying, and The Impact On Repurchase Intention (Case Study At Teenager Users Of Emina Cosmetics In Surabaya)
}

\author{
Dewi Apriliani $^{\mathrm{a}^{*}}$, I Gede Arimbawa $^{\mathrm{b}}$, Ani Wulandari ${ }^{\mathrm{c}}$ \\ ${ }^{a}$ Faculty of Economics anda Business, Narotama University Surabaya, dewiapriliani199@gmail.com \\ ${ }^{b}$ Faculty of Economics anda Business, Narotama University Surabaya, gede.arimbawa@narotama.ac.id \\ ${ }^{c}$ Faculty of Economics anda Business, Narotama University Surabaya, Jawa Timur, ani.wulandari@narotama.ac.id
}

\begin{abstract}
This study aims to analyze the influence and significance of YouTube beauty vlogger review, self congruity and price perception to impulse buying as well as their impact on the repurchase intention of young girls using Emina cosmetics in Surabaya. This research was using a quantitative method. The research data are primary data obtained from a sample of 100 young girls of Emina cosmetics users in Surabaya as the respondents. Data collected from online questionnaires and then analyzed using Partial Least Square (PLS) which processed by SmartPLS 3 version 3.6.8 software. The result of this research indicated that YouTube beauty vlogger review did not have a significant impact on impulse buying and repurchase intention. While the self-congruity and price perception significantly affected impulse buying and repurchase intention. Therefore, Emina should be focusing to strengthen its brand identity and maintain the affordability of their product rather than collaborating with beauty vlogger as their promotion strategy.
\end{abstract}

Keywords: Youtube Beauty Vlogger Review, Self Congruity, Price Perception, Impulse Buying, Repurchase Intention

\section{Introduction}

Currently the demand for beauty products such as makeup, skincare, body care and so on have become a primary need for Indonesian women and makes the demand for beauty products is increasing. Republic Indonesia's Ministry of Industry recorded that in 2017, the national cosmetics industry rose to 7.36 percent in the first quarter of 2018 . With this large market potential many local and international cosmetic brands are competing to launch their latest beauty products. One local cosmetic brand is being talked about is 'Emina'. Emina cosmetics is the first local cosmetic brand choose young women as the main target markets, with their claim that Emina's product has a lightweight formula that is very suitable for teenagers with natural and fresh make-up appearance, Emina is able to attract the attention of Indonesian people, especially the teenagers .

The following are five most talked brands by social media users, especially Twitter.

The survey results in one of the social media namely Twitter showed that Emina was included in the category of "Top 5 most talked about brands on Twitter" in 2017, Emina showed good development even they are relatively new in the Indonesian beauty industry, but Emina still inferior to old products like Sariayu and Purbasari. In fact, Emina's promotion relatively more active, especially on social media such as Instagram, Youtube and Facebook compared to other brands such as Sariayu and Purbasari, Emina also collaborates with the beauty vlogger, celebrities or famous artists as their brand ambassadors or partnership in some events which organized by Emina.

* Corresponding author.

E-mail address: dewiapriliani199@gmail.com (Dewi Apriliani) 


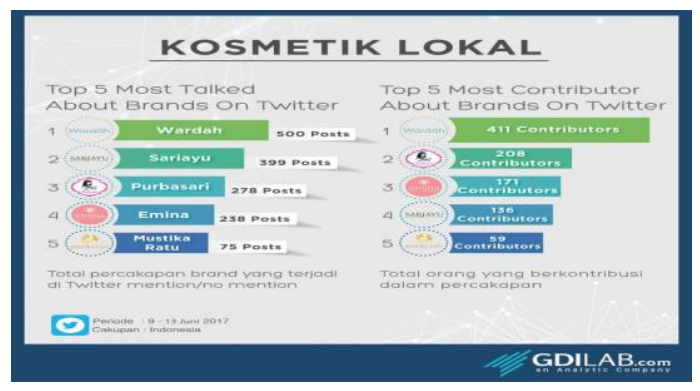

Figure 1 The results of a survey of local cosmetic 5

Source: GDILAB.com, 2017

Emina products have also very often become products that are mentioned in the beauty vloggers video as a reviewed or recommended products. This should be able to facilitate Emina in product promotion, because for a little more videos from this beauty vlogger will help Emina to introduce their products. As presented Hsu, et al (2014), who revealed that "Vlog is one of the popular forms of eWom, which is considered by online users as a very credible source among sources from other media".

Selecting youth as the main target which is different from previous brands is a challenge for Emina because the teenagers certainly has their own point of view about a product. Many things can affect the teenager's perception about Emina, one of them is about how Emina can truly reflect the teenage characters in their products. This compliance will affect the interest of the teenagers to Emina's product, as submitted by Sirgy (1982), Sirgy mention that the self-congruity (concordance between the self-image of individuals with the image of a product) influencing consumer decision making, such as a preference for the product and the desire to make a purchase.

This factor which is closely related to consumer behavior makes researchers would like to examine further whether the beauty vlogger who reviews Emina products, the suitability of the brand image formed by Emina with the selfconcept of adolescents and teenagers' perceptions about the price of Emina products can be a trigger for impulsive purchases from teenagers to how these factors ultimately impact the interests of teenage consumers to repurchase beauty products from Emina Cosmetics.

Previously, there were also researchers who conducted research related to several factors such as the research conducted by Yanhong Chen, et al 2019, the results of this study indicate that the product recommendation variable from social media only affected impulsive purchases by $43.9 \%$ while the rest was influenced by other variables which not included in the study. Next, Vania Vigolo, 2016 tested the Self Congruity variable to find results that had a positive effect on consumer repurchase interest but instead the actual self congruity variable originating from within had a smaller influence value than the personality formed by the views of the general public. Edo Praditya, 2016 and Ike Kusdyah also found that price perception had no significant effect on repurchase intentions. From the results of these studies there are still many irregularities that make researchers more interested in conducting research on these variables, moreover most research in Indonesia only discusses the influence of vlogger review on buying interest or purchasing decisions, no one has ever done research on the influence of beauty vlogger review on impulsive buying decisions and how their impact on repurchase intentions, especially for objects among teenage girls who use cosmetics in the Surabaya area.

\section{Literature review}

\subsection{Beauty Vlogger Review}

Beauty vlogger is a beauty influencer who shares information that teaches specific skills and describes how to do something with the content through video clips that subsequently posted on the YouTube platform (Choi and Behm- 
Morawitz, 2017). Choi and Morawitz (2017) also added that YouTube video content created by beauty vlogger can be classified into six types: how to (tutorial), review, out fit-of-the-day, get-ready-with-me, shopping hauls, and favorite videos. Dimensions of beauty vlogger review according to Kurniasari (2017: 28) include Trustworthiness with measurement indicators according to Ohanian (1990) :
1. Honest
2. Reliable
3. Sincere
4. Trustworthy

The second dimension is Expertise with indicators to measure it according to Ohanian (1990) in Ananda and Wandebouri (2016):

1. Knowledgeable

2. Advanced

3. Experienced

4. Qualified

5. Expert

Hypothesis 1: Vlogger Review has a significant effect on Impulse buying

The better the review from You Tube beauty vlogger, the more it will encourage impulsive buying on consumers. This was confirmed by the results of research from Eliza \& Sinaga (2018) which indicates that You Tube Beauty vlogger has a significant effect on consumer purchasing decisions with a percentage of $46.90 \%$.

Hypothesis 2: Vlogger Review has a significant effect on Repurchase intention

The better the review from You Tube beauty vlogger, the consumer repurchase interest will increase. Video blogging or vlogging as an effective form of communication over the past few years, now vlogs, one of the popular eWOM platforms, are considered by online users to be very reliable sources among all sources in different media (Biel and Daniel, 2012). Lupiyoadi, 2013 stated that to increase the number of sales, it can refer to consumer buying interest, including Brand image and word of mouth.

\subsection{Self congruity}

Self-Congruity is the suitability of brand attributes with consumer self-concept (Solomon, 2009). The same statement about self congruity was also expressed by Sirgy and Greskowiak (2007) who stated that self congruity is a match between brand image and consumer self. According to Schiffman \& Kanuk (2008) in Mayasari, Jilani, and Albar, 2019 self image congruity consists of four indicators namely:

1) Actual self-concept,

2) Ideal self-concept,

3) Actual social self-concept,

4) Ideal social self-concept,

Hypothesis 3: Self congruity has a significant effect on Impulse buying

The more suitable the brand is with the consumer's personality, the more the consumer will become an impulsive buyer. This thinking is supported by the results of research from Rorong, Mandey, \& Soepeno (2018) which shows that Consumer Image has a significant influence on purchasing decisions for Viva cosmetic products.

Hypothesis 4: Self congruity has a significant effect on Repurchase intention

The more suitable the brand with the consumer's personality, the consumer's repurchase interest will be increased. Ibrahim and Najjar (2007) in Widjiono and Japarianto, 2015 stated that Self Image Congruity can influence 
repurchase interest because someone has a motive to behave in accordance with his perception. Thus it can be said that the more appropriate the self image congruity, the better the attitude and interest in repurchasing the product or service.

\subsection{Price perception}

Price perception is the customer's judgment and associated emotional form about whether the price offered by the seller and the price compared to other parties are reasonable, acceptable or justifiable (Xia et al in Lee and LawsonBody, 2011).

According to Kotler and Armstong (2008), there are four indicators that characterize the price, namely:

1) Affordability of prices

2) Suitability price with quality products and services

3) Price competitiveness

4) Suitability price with benefits

Hypothesis 5: Price perception significantly influence Impulse buying

The better perception of consumer about products price will increasingly encourage impulsive buying of consumers. Zhou and Wong (2003) in Zhou and Gu, 2015 states that the price is always considered as a very important factor in encouraging impulse buying.

Hypothesis 6: Price perception has a significant effect on Repurchase intention

The better perception of the consumer about product price, the consumer's interest in repurchasing will increase. In a research journal created by Resti \& Susanto, 2016 mentioned that in marketing, perception of price is an important factor in creating customer satisfaction, satisfied consumers will be interested in repurchasing the service or product. The results of this study also showed that the price perception variable positive and significant impact on the buying repurchase intention.

\subsection{Impulse buying}

Impulse buying is the process of purchasing an item, where the buyer does not have the intention to buy before, it can be said to purchase without a plan or immediately purchase (Lisda, 2010: 56). According to Arnold and Reynolds (2003), an impulsive buying occurs when a person sees a product and suddenly want to buy the product, after it was decided to make a purchase at that time. To measure the level of impulse buying itself Bong, Soesono (2011) mentions that the indicators Impulsive buying, among others:

1) Purchase without a planned beforehand

2) Purchases without thinking about the consequences

3) Purchasing which influenced by emotional state

4) Purchasing which influenced by attractive offers.

Hypothesis 7: Impulse buying has a significant effect on Repurchase intention

The better results of consumer impulsive buying, the consumer's repurchase intention on the product will increase. In his research Suryana \& Dasuki (2013:195) In his research, Suryana \& Dasuki (2013: 195) argues that consumers will evaluate their buying decisions and actions. If a product purchased with an experiment turns out to be satisfying or exceeding expectations, the consumers are willing to make repeat purchases. 


\subsection{Repurchase intention}

Repurchase intention is a consumer's decision to repurchase a product or service based on what is obtained from the same company, make expenses to obtain these goods and services and tendencies to be done periodically. The accumulation of consumer experience and knowledge of a brand is a factor that can influence consumers to buy back the same brand (Hellier et al, 2003).

According to Ferdinand (2002) there are four indicators to identify repurchase interests, including;

1. Transactional interest

2. Preferential interest

3. Referential interest

4. Explorative interest

\subsection{Research framework}

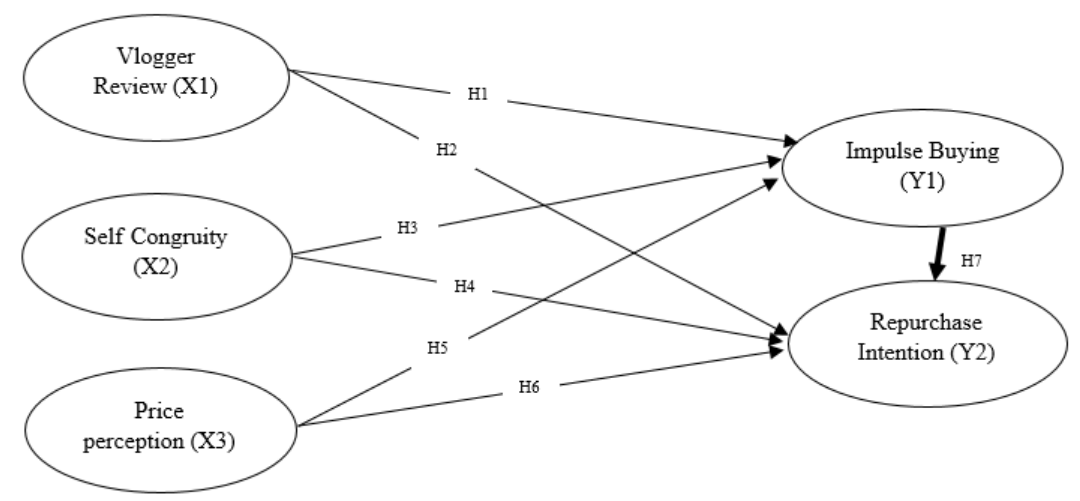

Figure 2 Research framework

\section{Research method}

The type of data used in this study is quantitative data. The data source in this study is primary data by taking a sample of 100 respondents from a population of young girl aged 15 to 21 years in Surabaya who use Emina's cosmetic products. Data collection techniques employed a questionnaire, this questionnaire will contain personal data of respondents and some questions which are based on indicators in each of the variables used in this study. The questions in this research questionnaire consisted of questions that could provide information for researchers' test material needs regarding You Tube beauty vlogger review, self congruity and price perceptions of impulse buying and repurchase intention of Emina cosmetic products in Surabaya.

The scale of measurement indicators in this study using a Likert scale which has five levels of preference with each having a score of 1 until 5. Data analysis in this study uses Partial Least Square (PLS) with SmartPLS 3 Version 3.6.8 software as a tool to process the data.

\section{Result and discussion}

In assessing the model by using PLS starts by looking R-square adjusted for each dependent latent variables. Rsquare adjusted value for Impulse Buying variable obtained a value of 0.216 and for Repurchase Intention variable obtained value of 0.631 . These results indicate that the Impulse Buying variable can be influenced by the variable Beauty Vlogger Review, Self Congruity and Price Perception by $21.6 \%$ and the rest is influenced by other factors 
while Repurchase Intention can be influenced by the variable Beauty Vlogger Review, Self Congruity and Price Perception by $63,1 \%$ and the remaining $36.9 \%$ are influenced by other factors which not examined in this study.

Table 1. Test Results Path Coefficient

\begin{tabular}{|c|c|c|c|c|c|}
\hline Path Coefficient & $\begin{array}{c}\text { Original } \\
\text { Sample } \\
\quad(O)\end{array}$ & $\begin{array}{c}\text { Sample } \\
\text { Mean } \\
(M)\end{array}$ & $\begin{array}{c}\text { Standard } \\
\text { Deviation } \\
(\text { STDEV })\end{array}$ & $\begin{array}{c}\text { Statistic } t- \\
(10 / \text { STDEV1) }\end{array}$ & P-Value \\
\hline BVR (X1) -> IB (Y1) & 0095 & 0107 & 0123 & 0771 & 0442 \\
\hline BVR (X1) -> RI (Y2) & 0099 & 0116 & 0068 & 1,441 & 0151 \\
\hline $\mathrm{SC}(\mathrm{X} 2)->\mathrm{IB}(\mathrm{Y} 1)$ & 0268 & 0257 & 0132 & 2,037 & 0043 \\
\hline $\mathrm{SC}(\mathrm{X} 2)->\mathrm{RI}(\mathrm{Y} 2)$ & 0461 & 0450 & 0101 & 4,559 & 0000 \\
\hline PP (X3) -> IB (Y1) & 0213 & 0224 & 0097 & 2,195 & 0029 \\
\hline PP (X3) -> RI (Y2) & 0374 & 0375 & 0065 & 5,720 & 0000 \\
\hline IB (Y1) -> RI (Y2) & 0221 & 0224 & 0088 & 2497 & 0013 \\
\hline
\end{tabular}

Source: Data processed by SmartPLS 3.6.8, 2020

\subsection{Direct impact}

\section{Hypothesis 1: Vlogger Review has a significant effect on Impulse Buying}

The results of data processing showed that the first hypothesis was rejected because the t-statistic value was $0.771<\mathrm{t}$ table 1.985 and the value of $\mathrm{p}$-value was $0.442>0.05$. The results of this study contradict with the results of research conducted by previous researchers namely Sinaga and Kusumawati (2018) in their journal entitled "The influence of You Tube beauty vlogger on consumer buying interest and its impact on purchasing decisions of Maybelline cosmetics in Indonesia", the results of the study showed that You Tube beauty vlogger variable has a significant influence on consumer purchasing decisions. However, the research also explained that the influence of beauty vlogger is only $46 \%$, which means that beauty vlogger does not have a very dominant influence on purchasing decisions. Moreover, seen from the average results of respondents' answers in table 4.6, it would be clear that the lowest average results in statements 4 and 5 regarding honesty and credibility level of the beauty vlogger, this is one of the factors causing You Tube beauty vlogger review to not have Significant influence on impulse buying is because respondents still feel less trust in the review conducted by the beauty vlogger.

This shows that Emina's product review conducted by beauty vlogger is not able to make consumers feel they want to buy Emina cosmetics directly.

\section{Hypothesis 2: Vlogger Review has a significant effect on Repurchase Intention}

The results of data processing showed that the second hypothesis was rejected because the $\mathrm{t}$-statistic value $1.441<\mathrm{t}$ table 1.985 and the value of $\mathrm{p}$-value $0.151>0.05$. The results of this study are inversely proportional to the results of Nilawati's research (2019) entitled "The Effect of Brand Image and Word of Mouth on Repurchase Interest" which 
states that there is a significant influence between WOM and repurchase intentions. Vlogger review which is one of the popular forms of e-WOM (Biel and Daniel, 2012) should be considered a trusted source by social media users. But in the scope of young girl it turns out that beauty vlogger review is still not enough to encourage their desire to re-purchase cosmetic products Emina. Looking back at the results of the average distribution of respondents' answers, it appears that the results show a good response that the respondent agrees in terms of having a desire to repurchase Emina cosmetic products, this shows that the respondent believes that other variables such as self congruity and price perception is a factor that is more able to encourage respondents' desire to make repeat purchases.

This exhibits that the more beauty vlogger reviews of Emina cosmetics will not further increase the desire of consumers to make repeat purchases.

\section{Hypothesis 3: Self Congruity has a significant effect on Impulse Buying}

The results of data processing showed that the third hypothesis was accepted because the t-statistic value was 2,037 > $\mathrm{t}$-table 1,985 and the value of $\mathrm{p}$-value was $0.043<0.05$. The results of this study are in accordance with the theory put forward by Kotler (2012) which defines all forms of purchasing decisions as choices found in consumers when choosing a brand.

This displays that the more appropriate Emina's brand image with the consumer's self-image of teenagers, the more it will encourage consumers to make impulsive buying.

\section{Hypothesis 4: Self Congruity has a significant effect on Repurchase Intention}

The results of data processing show that the fourth hypothesis is accepted because the t-statistic value is $4,559>\mathrm{t}$ table 1,985 and the value of $p$-value is $0,000<0.05$. The results of this study are supported by Ugolini's (2016) study entitled "Does this fit my style? The role of self congruity in young women's repurchase intention for intimate apparel" with the results of research showing that Self Cogruity has a significant effect on Repurchase Intention. The results in this study are also in accordance with the theory put forward by Ibrahim and Najjar (2007) in Widjiono and Japarianto (2015) which states that self image congruity can affect repurchase intention because someone has a motive to behave in accordance with his perception.

This indicates that the more appropriate Emina's brand image with the consumer's self-image of teenagers, the more consumer interest will be to repurchase Emina cosmetic products.

\section{Hypothesis 5: Price Perception significantly influence Impulse Buying}

The results of data processing showed that the fifth hypothesis was accepted because the t-statistic value was $2.195>$ t-table 1.985 and the value of p-value was $0.029<0.05$. The results of this study was supported by the results of Zhou \& Gu's (2015) study entitled "The Effect of Different Price Presentations on Consumer Impulse Buying Behavior" with the results of research showing that price presentations have a significant impact on consumer impulsive buying behavior. In addition, the results of this study are also in accordance with the theory of Zhou \& Wong (2003) which states that price is always considered as a very important factor in encouraging impulsive buying.

This shows that the more appropriate and affordable the price of Emina cosmetic products by teenagers, the urge for teenagers to make an impulsive buying of Emina cosmetics will also escalated.

\section{Hypothesis 6: Price Perception has a significant effect on Repurchase Intention}

The results of data processing revelaed that the sixth hypothesis is accepted because the t-statistic value is $5,720>\mathrm{t}$ table 1,985 and the value of $\mathrm{p}$-value is $0,000<0.05$. The results of this study are supported by Resti and Soesanto's (2016) research entitled "The effect of price perception, service quality through customer satisfaction on repurchase 
interest in Sifra's beauty home in Pati" with the results of research showing that price perception has a positive and significant effect on buying interest Sifra's beauty home.

This showcases that the more appropriate and affordable the price of Emina cosmetic products according to consumers, the consumer's interest in making repeat purchases will also increase.

\section{Hypothesis 7: Impulse Buying has a significant effect on Repurchase Intention}

The results of data processing showed that the seventh hypothesis was accepted because the $t$-statistic value was $2.497>$ t-table 1.985 and the value of $p$-value $0.013<0.05$. The results of this study are in accordance with the theory put forward by Suryana \& Dasuki (2013: 195), in their research Suryana and Dasuki argue that consumers will evaluate their decisions and actions in buying. If a product purchased with an experiment turns out to be satisfying or exceeding expectations, the consumer wants to make a repeat purchase.

This shows that the higher level of impulsive buying on Emina's cosmetic products, the higher consumer's interest in repurchasing the cosmetic products.

\subsection{Indirect Influence}

Based on the results of the analysis conducted using SmartPLS, it can be concluded that the variables Beauty Vlogger Review, Self Congruity and Price Perception do not affect indirectly on Repurchase Intention through Impulse Buying. The results demonstated that the t-statistic value smaller than t-table and $\mathrm{p}$-value greater than 0.05 can mean that the impulse buying variable as an intervening variable in this study is less able to be a mediator so it cannot strengthen the influence of Beauty Vlogger Review, Self Congruity and Price Perception, which are independent variables of repurchase intention as depen- dent variables. These results are inversely proportional to some previous studies that also use impulse buying as an intervening variable such as research conducted by Mayasari (2019) with the research title "The Influence of Fashion Lifestyle, Sales Promotion and Self Image to Impulse Buying Behavior and Customer Satisfaction", the results Mayasari's research shows that impulse buying has a significant effect and can be an intervening variable for customer satisfaction based on the results of the t-statistic test that is greater than t-table 1,661 and the p-value is smaller than 0.05. Besides Tobing (2019) on the results of his research entitled "The Effect of Utilitarian and Hedonic Shopping Value on Impulse Buying and Its Effect on Repurchase Intention of Fashion Products in Online Stores (Case Study of Online Shopee Consumers in Pontianak)" found that impulse buying has an influence which is significant towards repurchase intention and is able to be a mediator between the independent and dependent variables.

Impulse buying is less able to be a mediator variable in this study is reasonable, looking back to the results of the RSquare test where the test results for the variable impulse buying only has an effect of $21.6 \%$ while the rest is influenced by other factors which is not discussed in this study. This small percentage can be the reason why impulse buying is less able to be a mediator to increase the influence of Beauty Vlogger Review, Self Congruity and Price Perception on repurchase intention variables. Then the object in this study is the user of a beauty product that will not be chosen haphazardly by a woman, cosmetics users will think carefully about the possibility of compatibility of cosmetic products with their skin condition even when a woman has felt compatible with a cosmetic product of course she will reluctant to change the brand of cosmetic products. This is the reason why in this study the impulse buying variable according to Rook and Fisher (1995: 306) is the tendency of consumers to buy spontaneously, reflexively, suddenly, and automatically and make consumers no longer able to think rationally about the products they This purchase is less able to be a mediator because it is very unlikely that cosmetic users make purchases of beauty products suddenly without first knowing about the product. 


\section{Conclusion}

The results of data processing showed that there was a significant influence between the variables of self congruity and price perception on the impulse buying and repurchase intention of teenage girls using Emina cosmetics in Surabaya. The teenagers agreed that appropriate brand identity Emina their personality and an affordable price according to these young people were able to encourages them to make impulsive purchases and can make teenagers interested in repurchasing Emina cosmetic products. In this study it was also found that the beauty vlogger review variable did not significantly influence the impulse buying and repurchase intention, this shows that Emina's product review conducted by beauty vlogger was less able to make consumers feel like wanting to directly buy Emina cosmetic products so that it could not arouse consumer interest to repurchase Emina products.

\subsection{Limitation}

Limitations of this study is the validity of these results can not be generalized because of this research data is only sourced from one industry, as well as measurement of impulse buying and repurchase intention variables with independent variables Youtube beauty vlogger review, self congruity and price perception. Besides this research is not specific in determining the beauty vlogger to be used as an object of research, so the results in the You Tube beauty vlogger review variable are random and not specific.

Subsequent research can be directed by expanding populations and samples and increasing the scope of companies in the same field, so as to increase empirical validity, and further research can explore the role of other independent variables on impulsive buying behavior and customer satisfaction.

\subsection{Future research}

Further research can conducted on the relationship between You Tube beauty vlogger review with impulse buying and with the interest of repurchasing local cosmetic products in Indonesia by using more specific research indicators, for example by determining which beauty vlogger will be used as a research indicator so that research results can be more specific. Research using a wider population and more diverse variables in the beauty industry is certainly expected in the future.

\section{References}

Arnold, MJ, \& Reynolds, KE (2003). Hedonic shopping motivations. Journal of Retailing. https://doi.org/10.1016/S0022-4359(03)00007-1

Chen, Y. Lu, Y., Wang, B., \& Pan, Z. (2018). School of Management SC. Information \& Management. https://doi.org/10.1016/j.im.2018.09.002

Chin, WW (1998). The Partial Least Squares aproach to Structural Equation Modeling. Modern Methods for Business Research, 295, 336

Denniswara, EP (2016). EFFECT OF QUALITY PRODUCTS, PRICE AND PROMOTION OF PRODUCTS MY BIRTHDAY purchase intention IDEAS. PERFORMANCE: Journal of Management and Business Start-Up, 1.

Dewi, Magdalena, PD (nd). The influence of word of mouth, income level and quality of products on purchase decisions that have an impact on the consumer buying interest (a case study on juvenile milkfish products elrina Semarang). 1-19.

Dhaneswara, AP, Hidayanto, AN, \& Zhu, Y. (2018). Vlogging: Trigger to Impulse Buying Behaviors vlogging: Trigger to Impulse Buying Behaviors.

Eliza, R., \& Sinaga, M. (2018). EFFECT ON YOUTUBE Vlogger BEAUTY PRODUCTS PURCHASED INTEREST (Studies in Maybelline Cosmetics Users in Indonesia). 63 (1), 187-196.

Ferdinand, Augusty 2002, Development Interests Buy Brand Extension, Semarang: Diponegoro University Publishers Agency. 
Ghozali, Imam. 2006. Applications Multivariate Analysis with SPSS (Edition 4). Semarang: Diponegoro University Publishers Agency.

Hellier, Philip K, Guesen Gus M, Rodney Carr A, and Rickard John A. 2003. Customer Repurchase Intention A General Structural Equation Model. Journal of Marketing, Vol.37, pp: 1762-1800

Kotler, Philip. 2009. Marketing Management. Issue thirteen languages and 2.Jakarta Indonesia.Jilid 1: Erland.

Kurniasari, I. (2017). Effect of Country Image and Beauty Vlogger Revew against Korea Cosmetics Consumer Purchase Intention.

Kusdyah, I. (2012). DESIRE TO PURCHASE RE CLINIC HEALTH SERVICES (CASE STUDY Erha Clinic SURABAYA). 7 (1), 25-32. https://doi.org/10.9744/pemasaran.7.4.25-32

Lupiyoadi, R. (2013). Marketing Management services, Jakarta: Four Salemba. Marketing Management Services, Jakarta: Four Salemba.

Mayasari, D. (2019). The Influence of Fashion Lifestyle, Sales Promotion and Self-image to Impulse Buying Behavior and Customer Satisfaction. Journal of the World Conference.

Mayasari, H., Jilani, A., \& Albar, BB (2019). Effect of Self Image Congruity and Quality of Service to the Customer. 2, 48-59.

McCracken, G. (1989). Who is the Celebrity Endorser? Cultural Foundations of the Endorsement Process. Journal of Consumer Research. https://doi.org/10.1086/209217

Mulyadi, M. (2013). QUANTITATIVE AND QUALITATIVE RESEARCH THINKING AND BASIC combine. Journal of Communication and Media Studies. https://doi.org/10.31445/jskm.2011.150106

Nilawati, W. (2019). Influence of Brand Image And Word Of Mouth To Purchase Interests Birthday (Study on Consumer Pancoran Kopi ABC In the village of Bondowoso). 9 (1), 74-78.

Ohanian, R. (1990). Construction and validation of a scale to measure celebrity endorsers' perceived expertise, trustworthiness, and attractiveness. Journal of Advertising. https://doi.org/10.1080/00913367.1990.10673191

Marketing, PM, Economy, F., \& Petra, UK (2015). ANALYSIS OF EFFECT OF SELF IMAGE CONGRUITY, RETAIL SERVICE QUALITY AND CUSTOMER REPURCHASE Perceived Service Quality OF INTENTION TO CUSTOMER SATISFACTION as an intervening variable Barbershop BROADWAY IN SURABAYA. 9 (1), 35-42. https://doi.org/10.9744/pemasaran.9.1.35-42

Premayani, WW, Ayu, IG, Giantari, K., \& Kerti, NN (2018). The Effect Of Self Image Congruity And Functional Congruity To Attitudes And Repurchase Intention. 20 (2), 8-11. https://doi.org/10.9790/487X-2002070811

Resti, D., \& Susanto, H. (2016). Influence the perception of price, service quality through customer satisfaction with the buying interest in beauty home Sifra in starch. 5, 1-12.

Rook, DW, \& Fisher, RJ (1995). Normative Influences on Impulsive Buying Behavior. Journal of Consumer Research. https://doi.org/10.1086/209452

Rorong, IL, Mandey, SL, \& Soepeno, D. (2018). Influence Consumer Image and Imagery Products Buying Decision Against Viva Cosmetic Products. Journal EMBA.

Have now, U. (2011). Research Methods for Business. Jakarta: Four Salemba.

Sirgy, MJ (1982). Self-concept in consumer behavior: a critical review. Journal of Consumer Research, 9, 287-300.

Sugiyono. (2009). Quantitative Research Methods, Qualitative and R \& D. Bandung: Alfabeta.

Sugiyono. (2010). Business Research Methods. Quantitative Approach, Qualitative and R \& D Bandung: Alfabeta.

Sugiyono. (2017). Approach Quantitative, Qualitative, combination, R \& D and Research Evaluation. In research methodology.

Suryana, P., \& Dasuki, ES (2013). Analysis of Factors Influencing Purchase Decision and Its Implications on Interests Buy Re. TRIKONOMIKA. https://doi.org/10.23969/trikonomika.v12i2.479

Ugolini, VVMM (2016). "Does this fit my style? The role of self-congruity in young women's repurchase intention for intimate apparel", Journal of Fashion Marketing and Management: An International Journal, Vol. 20 Iss 4 pp. http://dx.doi.org/10.1108/JFMM-02-2015-0016intention for intimate apparel. 
Zhang, Xu, Zhao. (2016). Online reviews and impulse buying behavior: the role of browsing and impulsiveness.

Zhou, H., \& Gu, Z. (2015). The Effect of Different Price Presentations on Consumer Impulse Buying Behavior: The Role of Anticipated Regret. (January), 27-36.

Zhou, L., \& Wong, A. (2003). Consumer impulse buying and in-store stimuli in Chinese supermarkets. Journal of International Consumer Marketing, 16, 37-53. 